\title{
IN VITRO ACTIVITY TEST OF Murayya koenigii L. SPRENG LEAVES AS A NATURAL PRESERVATIVE FOR TILAPIA FISH MEAT
}

\author{
Su' $^{\text {adah }^{1}}{ }^{\text {, }}$ Vivi Mardina ${ }^{1 *}$, Fadhliani ${ }^{1)}$, \\ ${ }^{1}$ Program Studi Biologi, Fakultas Teknik, Universitas Samudra, Jl. Prof.Syarief Thayeb, Meurandeh, \\ Langsa Lama, Kota Langsa, Aceh, Indonesia 24416 \\ *email: vmardina@unsam.ac.id
}

\section{Article Info}

Article history:

Received

04/30/2021

Received in revised

05/21/2021

Accepted

$06 / 13 / 2021$

\begin{abstract}
Fish that are high in protein content are prone to quality degradation. This is strongly thought to be due to the influence of microbes that are inside or outside the fish's body. The use of formalin for food preservatives is not recommended because it can interfere with health. In Indonesia, there are many natural preservatives that are safer to use, such as Murayya koenigii L. Spreng which is rich in antioxidants and has antibacterial properties. This study aimed to evaluate the effect of $M$. koenigii leaf extract as an inhibitor of bacterial growth in Oreochromis. niloticus fish meat and to measure the maximum concentration of $M$. koenigii leaf extract. The study used a completely randomized design method (RAL) with one factor, namely the concentration of temurui leaf extract (Murayya koenigii L. Spreng) which consisted of concentrations of $0,10,20$, $40 \%$ ( $\mathrm{g} / \mathrm{mL}$ ). The data were taken on storage time, namely 0 days, 1 day, 2 days, and 3 days. The observation parameter used was the inhibition zone diameter $(\mathrm{mm})$ which was analyzed using one way ANOVA. The results showed that temurui leaves have the potential to be used as an inhibitor of microbial growth in O. niloticus fish meat at a concentration of $40 \%(\mathrm{~g} / \mathrm{mL})$ which is the maximum concentration.
\end{abstract}

Keywords:, Murayya koenigii L. Spreng, Oreochromis nilaticus, natural preservatives

\section{IN VITRO UJI AKTIVITAS DAUN Murayya koenigii L. Spreng SEBAGAI PENGAWET ALAMI PADA DAGING IKAN NILA}

\begin{abstract}
Abstrak
Ikan yang tinggi kandungan protein mudah mengalami penurunan kualitas. Hal ini diduga kuat akibat pengaruh mikroba yang terdapat di dalam atau diluar tubuh ikan. Penggunaan formalin untuk pengawet makanan tidak dianjurkan karena dapat mengganggu kesehatan. Di Indonesia banyak bahan pengawet alami yang lebih aman untuk digunakan seperti Murayya koenigii L. Spreng yang kaya antioksidan dan bersifat antibakteri . Penelitian ini telah bertujuan untuk mengevaluasi pengaruh ekstrak daun M. koenigii sebagai penghambat pertumbuhan bakteri pada daging ikan $O$. Niloticus dan mengukur konsentrasi maksimum ekstrak daun $M$. koenigii sebagai pemghambat pertumbuhan bakteri pada daging ikan $O$. niloticus. Penelitian menggunakan metode Rancangan Acak Lengkap (RAL) dengan satu faktor yaitu konsentrasi ekstrak daun temurui (Murayya koenigii L. Spreng) yang terdiri
\end{abstract}


atas konsentrasi $0,10,20,40 \%(\mathrm{~g} / \mathrm{mL})$. Data diambil pada lama penyimpanan yaitu adalah 0 hari, 1 hari, 2 hari, dan 3 hari. Parameter pengamatan yang digunakan yaitu diameter zona hambat $(\mathrm{mm})$ yang di analisa menggunakan one way ANOVA. Penelitian memiliki hasil bahwa daun temurui berpotensial untuk digunakan sebagai penghambat pertumbuhan mikroba pada daging ikan O. niloticus pada konsentrasi $40 \%(\mathrm{~g} / \mathrm{mL})$ yang merupakan konsentrasi maksimum.

Kata kunci: Murayya koenigii L. Spreng, Oreochromis nilaticus, Pengawet alami

\section{PENDAHULUAN}

Ikan merupakan salah satu hasil kekayaan alam laut Indonesia (Mardina dkk., 2018) yang banyak digemari oleh masyarakat untuk dijadikan bahan pangan . Salah satu ikan yang digemari di masyarakat adalah Oreochromis niloticus (Vitria, 2016). Menurut Sumartini dkk, (2014), O. niloticus mengandung protein sebanyak $43,76 \%$, lemak $7,01 \%$, kadar abu $6,80 \%$ per 100 gram berat ikan.

Disisi lain, ikan yang tinggi kandungan protein mudah mengalami penurunan kualitas. Hal ini diduga kuat akibat pengaruh mikroba yang terdapat di dalam atau diluat tubuh ikan. Mikroba sangat mudah tumbuh pada substrat yang menyediakan kadar protein tinggi dengan kandungan asam amino bebas (Apriyani dkk, 2017).

O. niloticus sendiri mulai mengalami penurunan kualitas fisik setelah 2 jam kematian, kerusakan ini dapat terjadi secara biokimia maupun mkrobiologi. Hal ini disebabkan oleh beberapa hal seperti kondisi lingkungan yang sangat sesuai untuk pertumbuhan mikroba pembusuk yang diakibatkan bakteri, khamir, maupun jamur. Perpanjangan daya simpan $O$. niloticus sehingga lebih awet dapat dilakukan dengan menurunkan kadar air atau menambahkan bahan pengawet yang mampu memperpanjang daya simpan $O$. niloticus (Hakim, 2010; David dkk, 2013).

Menurut Pemenkes No. 033 Tahun 2012, pengawet adalah bahan tambahan pangan yang digunakan untuk menghambat fermentasi, pengasaman, penguraian, dan perusakan lainnya terhadap pangan yang di sebabkan oleh mikroorganisme. Bahan pengawet dibedakan menjadi alami dan sintetik. Penggunaan bahan pengawet sintetik harus diatur dan diawasi dosis penggunaannya agar tidak menimbulkan kerugian bagi pemakainya, baik yang bersifat langsung misalnya keracunan maupun yang bersifat tidak langsung misalnya bahan pengawet yang bersifat karsinogenik (Sella, 2013). Sebagian masyarakat menggunakan pengawet sintesis yang berbahaya seperti formalin untuk mengawetkan ikan. Penggunaan formalin untuk pengawet makanan tidak dianjurkan karena dapat mengganggu kesehatan. Untuk menghindari efek negatif dari pengawet sintetik, pengawet/ proses pengawetan alami sangat dianjurkan. Salah satu pengawetan alami yang dilakukan oleh masyarakat agar daging ikan lebih awet biasanya adalah dengan pendinginan dan pengasapan/pengeringan (Aziz dkk, 2014)

Di Indonesia banyak bahan pengawet alami yang lebih aman untuk digunakan (Wardiny dkk 2013; Wafa, dkk 2014) seperti M. koenigii. Daun M. koenigii memiliki kandungan sebagai berikut air $(66,3 \%)$, protein $(1 \%)$, lemak $(1 \%)$, karbohidrat $(16 \%)$, serat $(6,4 \%)$, dan mineral (4,2\%). Kandungan mineral utama per 100 gram daun adalah kalsium (810 $\mathrm{mg}$ ), fospor $(600 \mathrm{mg})$ dan besi $(2,1 \mathrm{mg})$. Kandungan vitaminnya adalah karoten (12.600 i.u.), asam nikotinat (2,3 mg), dan 
vitamin $\quad \mathrm{C} \quad\left(\begin{array}{llll}4 & \mathrm{mg}\end{array}\right)$ serta memiliki kandungan alkaloid, selain kandungan gizi yang tinggi dari daun temurui, temurui juga kaya metabolit sekunder yaitu alkaloid, terponoid, saponin, flavonoid dan tanin (Sukma dkk, 2018). Menurut Rasyid (2016) metabolit sekunder dapat berfungsi sebagai penghambat pertumbuhan mikroba. Berdasarkan uraian diatas, penelitian ini bertujuan untuk mengetahui aktivitas $M$. koenigii sebagai penghambat proses pembusukan pada daging ikan $O$. niloticus.

\section{METODE PENELITIAN \\ Waktu dan Tempat Penelitian}

Penelitian telah dilaksanakan pada Maret hingga September 2020 di UPT Laboratorium Dasar Universitas Samudra Langsa. Sampel O. niloticus Segar dikoleksi dari tambak petani desa Sungai Pauh Tanjung Langsa Barat, kota Langsa. Adapun koleksi sampel daun temurui (Murraya Koenigii L. Spreng) di peroleh dari kota Langsa.

\section{Alat dan Bahan}

Alat yang digunakan dalam penelitian ini meliputi pisau, refrigerator, plastik polyethylene, timbangan digital, petridish steril (pyrex), tabung reaksi streril (pyrex), erlenmeyer steril, gunting, pinset, autoklaf, magnatic stirer, pembakar spiritus, mikropipet, lilin, toples, spatula, tips dan gunting. Bahan utama yang digunakan adalah $O$. niloticus dan $M$. Koenigii L. Spreng. Adapun bahan pendukung yaitu aluminium foil, aquades, alkohol 70\%, alcohol 96\%, spiritus, nutrient agar (NA), nutrient broth (NB), tissue, $\mathrm{NaCl}$ Fisologis dan kertas label (Aulya $d k k .$, 2020).
Rancangan yang digunakan pada penelitian ini adalah dengan menggunakan metode Rancangan Acak Lengkap (RAL) dengan satu faktor yaitu konsentrasi ekstrak daun temurui (Murayya koenigii L. Spreng) yang terdiri atas konsentrasi 0, 10, 20, 40\% (g/mL). Data diambil pada lama penyimpanan yaitu adalah 0 hari, 1 hari, 2 hari, dan 3 hari. Parameter pengamatan yang digunakan yaitu diameter zona hambat (mm) yang di analisa menggunakan one way ANOVA.

\section{HASIL DAN PEMBAHASAN}

\section{Hasil Uji Aktivitas Ektrak Daun Temurui Sebagai Penghambat Pertumbuhan Mikroba Secara In Vitro}

Hasil uji ekstrak daun temurui digunakan sebagai pengawet alami pada $O$, niloticus menggunakan metode difusi sumuran dengan parameter pengamatan adalah diameter zona hambat. Uji sumuran dilakukan pada konsentrasi 0\%, 10\% 20\% dan $40 \%(\mathrm{~g} / \mathrm{mL})$. Hasil uji ditampilkan pada Tabel 4.1. Adapun pengamatan diameter zona hambat ditampilkan pada Gambar 4.1a, b, c, dan d.

Tabel 4.1. Rerata diameter zona hambat (mm) pada pengujian ekstrak daun temurui sebagai penghambat pertumbuhan mikroba pada daging ikan $O$, niloticus

\begin{tabular}{ccccc}
\hline $\begin{array}{c}\text { Hari } \\
\text { ke }\end{array}$ & \multicolumn{4}{c}{ Konsentrasi (g/mL) } \\
\hline & $0 \%$ & $10 \%$ & $20 \%$ & $40 \%$ \\
\hline $\mathbf{0}$ & 0 & 0 & 0 & $21,66 \mathrm{~mm}^{\mathbf{a}}$ \\
\hline $\mathbf{1}$ & 0 & 0 & 0 & $18,5 \mathrm{~mm}^{\mathbf{a}}$ \\
\hline $\mathbf{2}$ & 0 & 0 & 0 & $15 \mathrm{~mm}^{\mathbf{b}}$ \\
\hline $\mathbf{3}$ & 0 & 0 & 0 & $4,5 \mathrm{~mm}^{\mathbf{b}}$ \\
\hline
\end{tabular}

\section{Rancangan Penelitian}




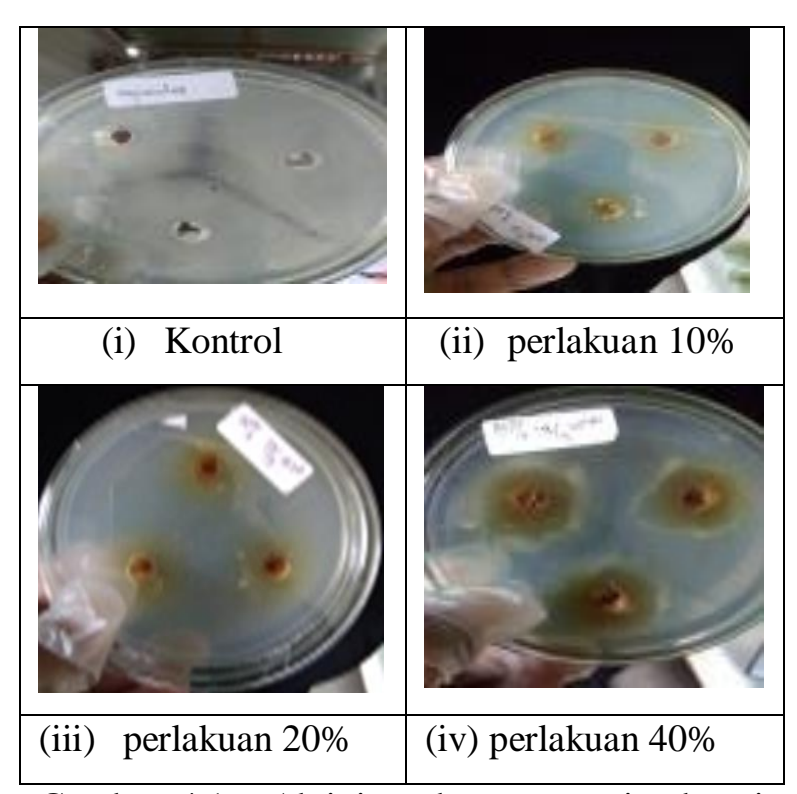

Gambar 4.1a. Aktivitas daun temurui sebagai penghambat pertumbuhan mikroba pada daging ikan nila yang dibiarkan 0 hari pada suhu ruang.

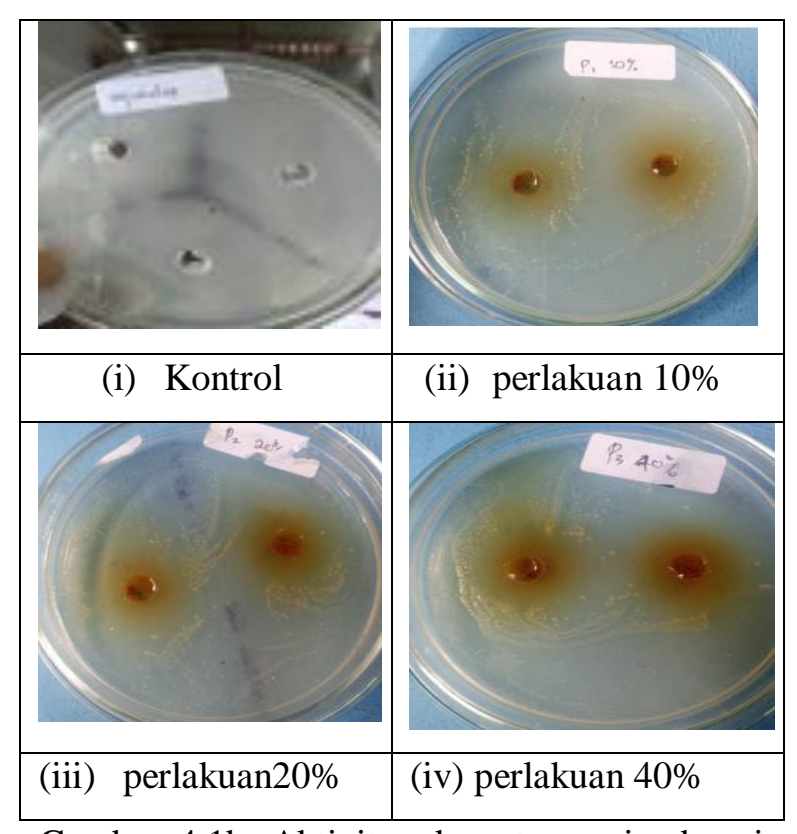

Gambar 4.1b. Aktivitas daun temurui sebagai penghambat pertumbuhan mikroba pada daging ikan nila yang dibiarkan 1 hari pada suhu ruang.

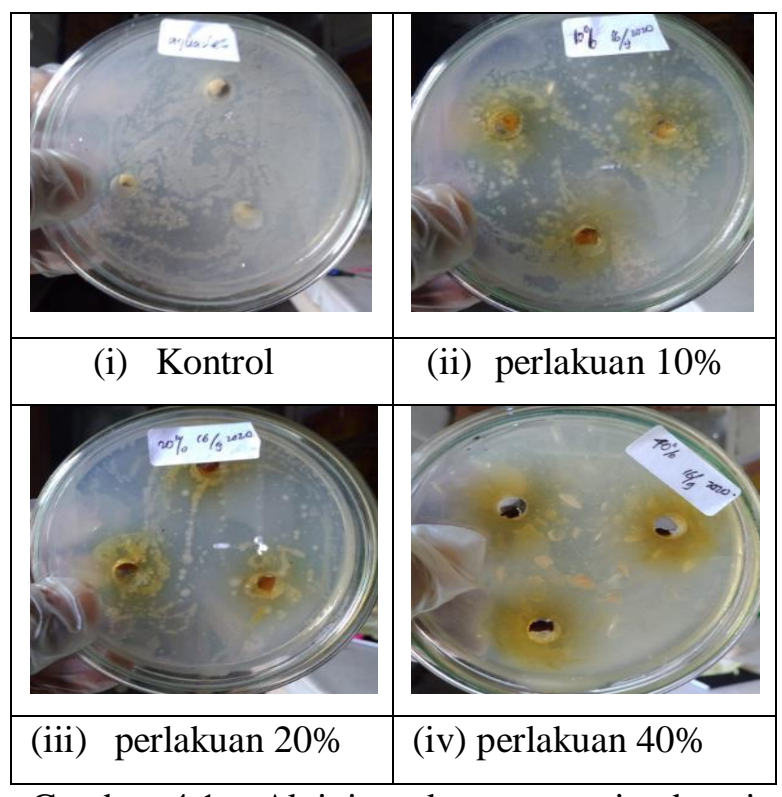

Gambar 4.1c. Aktivitas daun temurui sebagai penghambat pertumbuhan mikroba pada daging ikan nila yang dibiarkan 2 hari

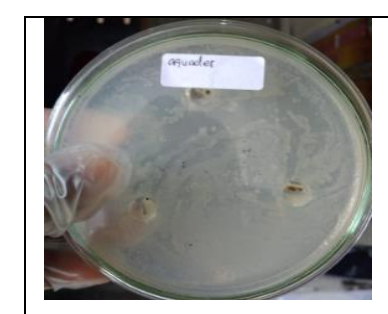

(i) Kontrol

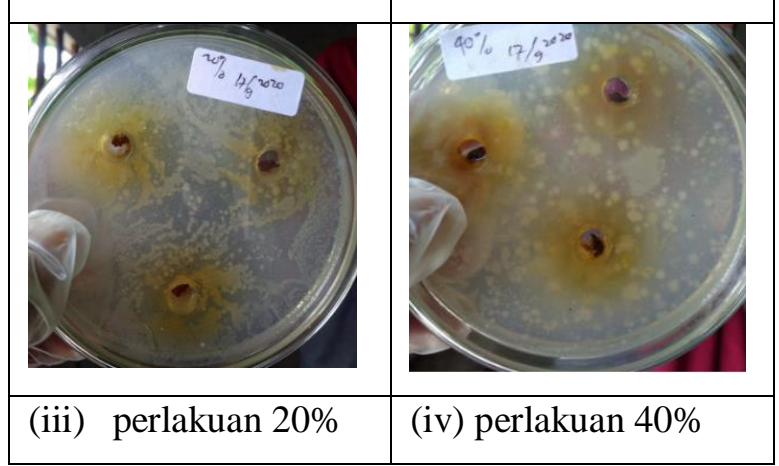

Gambar 4.1d. Aktivitas daun temurui sebagai penghambat pertumbuhan mikroba pada daging ikan nila yang dibiarkan 3 hari pada suhu ruang.

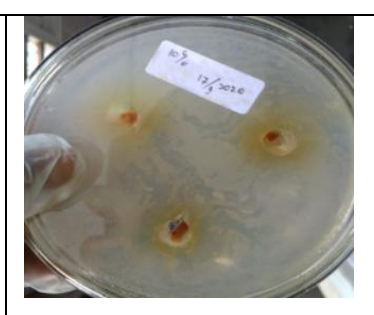

(ii) perlakuan $10 \%$ 


\section{Preparasi Ekstrak}

Maserasi adalah salah satu jenis metode ektraksi dengan sistem tanpa pemanasan atau bisa disebut dengan istilah ekstraksi dingin. Metode maserasi mempunyai banyak keuntungan di bandingkan dengan metode lainnya, keuntungan utama metode maserasi yaitu prosedur dan peralatan yang digunakan sangat sederhana dan tidak dipanaskan sehingga bahan alam tidak menjadi terurai, ektraksi dingin memungkinkan banyak senyawa terekstraksi meskipun beberapa senyawa memiliki kelarutan terbatas dalam pelariut pada suhu kamar (Manic dkk, 2014; ' Mardina dkk., 2020).

Pembuatan serbuk simplisia $M$. koenigi L. Spreng dilakukan dengan mengumpulan sampel sebanyak $6 \mathrm{~kg}$ yang diperoleh dari kota Langsa, kecamatan Langsa Lama. Daun segar di kering anginkan pada suhu ruangan dan tidak diberikan paparan cahaya matahari langsung selama \pm 20 hari. Setelah kering menjadi $2 \mathrm{~kg}$ sampel di potong-potong kecil kemudian dimasukkan dalam bejana, Setiap 6 ons sample direndam dengan 7 L etanol selama 3x 24 jam. Perendaman sampel diulang 3 kali dengan pengadukan setiap hari. Filtrat di saring menggunakan Whatman filter paper No.1 dan diperoleh hasil 14,84 L, kemudian dievaporasi secara manualpada suhu dibawah $40^{\circ} \mathrm{C}$ untuk memperoleh ekstrak kental sebanyak $\pm 25,4$ g ( ${ }^{\mathrm{a}}$ Mardina dkk., 2020; ' $\mathrm{b}$ ardina dkk., 2020; Vivi dkk., 2020).

\section{Aktivitas Ekstrak Temurui untuk Menghambat Pertumbuhan Mikroba pada Daging Ikan Nila secara In Vitro}

Metode yang digunakan pada penelitian ini adalah metode difusi sumuran yang disebut juga sebagai metode
Kirby bauer. Keuntungan metode difusi tidak memerlukan peralatan yang sophisticated sehingga relatif murah dan mudah dalam pengerjaannya. Keuntungan lain metode difusi sumuran ialah satu konsentrasi ekstrak dapat digunakan untuk menguji beberapa jenis mikroba (Tortora, 2010).

Pada penelitian ini, metode difusi sumuran menggunakan konsentrasi 0,10 , dan 20 dan $40 \% \quad(\mathrm{~g} / \mathrm{mL})$. Parameter pengamatan adalah diameter zona hambat. Sebanyak $0,2 \mathrm{~cm}^{3}$ daging ikan diambil dan diletakkan pada sumuran (diameter sumuran $\pm 0,8 \mathrm{~cm}$ ) yang diberi larutan ekstrak daun temurui sebanyak $200 \mu \mathrm{L}$. Inkubasi dilakukan pada suhu ruang selama 24 jam. Berdasarkan pada table 4.1 ditemui bahwa ekstrak temurui pada konsentrasi $40 \% \quad(\mathrm{~g} / \mathrm{mL})$ menunjukkan zona hambat yang maksimum terhadap aktivitas bakteri pembusuk pada ikan $O$. niloticus dengan zona hambat yaitu 21,7 mm pada 0 hari, $18.5 \mathrm{~mm}$ pada 1 hari, 15 mm pada hari ke-2 dan $4.5 \mathrm{~mm}$ pada hari 3. Adapun konsentrasi ekstrak control (0\%), 10\% dan $20 \%$ (g/mL) tidak ditemui zona hambat baik pada $0,1,2$, dan 3 hari. Semakin tinggi konsentrasi pengawet alami ektrak daun temurui yang digunakan maka semakin luas zona hambat yang terbentuk untuk menghambat pertumbuhan bakteri penyebab penurunan kualitas pada daging ikan nila.

Berdasarkan hasil analisa ANNOVA, pada perlakuan $40 \%(\mathrm{~g} / \mathrm{mL})$, rerata diameter zona hambat yang dihasilkan pada 0 hari tidak berbeda nyata dengan daging ikan nila yang dibiarkan 1 hari pada suhu ruangan. Namun berbeda sangat nyata dengan rerata diameter zona hambat yang dihasilkan pada 1 hari dan 2 hari. Untuk hasil pada daging ikan yang dibiarkan 1 dan hari pada suhu ruang, 
pemberian ekstrak daun temurui tidak berbeda nyata.

Aktivitas penghambat pertumbuhan mikroba penyebab penurunan kualitas daging ikan $O$. niloticus pada penelitian ini diduga karena kandungan metabolit sekunder yang ada pada daun Murraya Koenigii L. Spreng. Sukma dkk (2018) melaporkan bahwa bahwa ekstrak daun $M$. koenigii mengandung saponin, terpenoid/triterpenoid, alkaloid, glikosida, falvonoid, dan tanin. Menurut Niggapan dkk., (2011) senyawa flavonoid yang terkandung pada temurui dapat berfungsi sebagai antimikroba yang bekerja dengan merusak permeabilitas dinding sel bakteri, mikrosom, dan lisosom sebagai hasil interaksi antara flavonoid dengan DNA bakteri. Adapun menurut (Rastina, dkk., 2015) flavonid memiliki sifat lipofilik sehingga dimungkinkan akan merusak membran sel bakteri.

Flavonoid merupakan senyawa fenol. Senyawa fenol dapat bersifat koagulator protein. Flavonoid dapat berperan sebagai antibakteri dengan mengganggu fungsi organel bakteri. Flavonoid menghambat pertumbuhan bakteri dengan menyebabkan terjadinya kerusakan permeabilitas dinding sel bakteri, merusak membrane bakteri yang menyebabkan lisis serta merusak mikrosom dan lisosom. Adapun senyawa alkaloid mengganggu komponen penyusun peptidoglikan pada sel bakteri sehingga lapisan dinding sel tidak terbentuk secara utuh dan menyebabkan kematian sel tersebut (Fadhliani, 2020).

Fifendy (2017) dan Pelczar dan Chan, (2008) menyatakan bahwa suatu senyawa dalam tumbuhan dapat bersifat antimikroba dengan cara kerja: (1) merusak dinding sel bakteri, (2) merubah permeabilitas membrane sel bakteri, (3) mengganggu molekul protein dan asam nukleat pada bakteri dengan cara mendenaturasi protein penyusun membrane sel bakteri, (4) menghambat kerja enzim pada baketri yang mengakibatkan terganggunya metabolism dalam tubuh bakteri, (5) serta menghambat proses proses sintesa asam nukleat dan protein yang berakibat rusak total tubuh bakteri.

Hasil penelitian ini sejalan dengan penelitian Syifa (2003) yang melaporkan bahwa ektrak bawang putih dengan konsentrasi $20 \%$ efektif menghambat pertumbuhan bakteri yang diisolasi dari daging ikan bandeng dalam 24 jam. Penelitian yang dilakukan oleh Ayu (2010) menyimpulkan penggunaan Morinda citrifolia yang memiliki aktivitas anti bakteri dalam menghambat jumlah bakteri pada daging ikan tongkol pada konsentrasi $80 \%$ memiliki aktifitas hampir sama dengan formalin dalam menghambat jumlah bakteri pada daging ikan tongkol. Penelitian Roosiana (2015) juga menemukan bahwa penggunaan daun sirih pada ikan nila mampu menghambat populasi bakteri pada konsentrasi 30\% karena senyawa fenol mendenaturasi protein sel bakteri akibatnya semua aktivitas metabolisme sel bakteri terhenti.

$\begin{array}{clc}\text { Pelczar dan Chan (2008) } \\ \text { menjelaskan } & \text { mekanisme bahan }\end{array}$ antimikroba merusak dinding sel adalah karena dinding sel bakteri yang berfungsi mempertahankan bentuk dan menahan sel, tersusun atas peptidoglikan (polimer kompleks) yang terdiri atas rangkaian asam $\mathrm{N}$-asetil glukosamin dan asam $\mathrm{N}$-asetil muramat. Keberadaan lapisan peptidoglikan ini menyebabkan dinding sel bersifat kaku dan kuat sehingga mampu menahan tekanan osmotik dalam sel. Struktur dinding sel dapat dirusak dengan 
cara menghambat pembentukannya atau mengubahnya setelah selesai dibentuk. Bahan antimikroba pada konsentrasi rendah akan menghambat pembentukan ikatan glikosida sehingga pembentukan dinding sel yang baru akan terganggu. Konsentrasi tinggi pada bahan antimikroba akan menyebabkan ikatan glikosida menjadi terganggu dan pembentukan dinding sel terhenti.

Adapun mekanisme bahan antimikroba merubah permeabilitas sel adalah dengan menggangu fungsi membran sel (Pelczar dan Chan, 2008). Membran sel tersusun atas fosfolipid dan protein yang berfungsi untuk mengatur keluar masuknya zat-zat tertentu dalam sel. Terganggunya fungsi membran sel oleh adanya bahan antimikroba, menyebabkan permeabilitas sel bakteri akan mengalami perubahan, sehingga akan mengakibatkan terhambatnya pertumbuhan sel atau kematian sel (Campbell dkk, 2012).

Sel mikroba mengandung enzimenzim yang berperan dalam proses metabolisme. Kandungan metabolit sekunder dalam suatu bahan/tanaman dapat menggangu kerja enzim dengan cara menonaktifkan kerja enzim. Enzim yang tidak berfungsi mengakibatkan metabolisme mikroba menjadi lambat bahkan terhenti (Pelczar dan Chan, 2008).

\section{KESIMPULAN}

Penelitian yang telah dilakukan menyimpulkan bahwa hasil uji Difusi sumuran merekomendasikan bahwa daun temurui berpotensial untuk digunakan sebagai penghambat pertumbuhan mikroba pada daging ikan $O$. niloticus dan konsentrasi $40 \% \quad(\mathrm{~g} / \mathrm{mL})$ merupakan konsnetrasi maksimum ekstrak daun temurui (Murraya Koinigii) yang dapat menghambat pertumbuhan mikroba pada daging ikan nila penyebab proses pembusukan pada daging ikan.

Penelitian menyarankan penelitian lanjut tentang pengujian organoleptik dan uji in-vivo terhadap penghambat pertumbuhan mikroba pada daging ikan.

\section{DAFTAR RUJUKAN}

Apriani R, Ferasyi R, Razali R, (2017). Jumlah cemaran mikroba dan nilai organoleptik ikan tongkol (Euthynnus affiinis). JIMVET 1(3): 598-603.

Aulya W, Fadhliani, Mardina V. (2020). Analysis of coliform and colifecal total pollution test on various types of drinking water using the MPN (most propable number) method. Serambi Journal of Agricultural technology, 2 (2): $64-72$.

Ayu, V, S. (2010). Pengaruh Konsentrasi Ekstrak Etanol Buah Mengkudu (Morinda citrifolia) danWaktu Penyimpanan terhadap Kualitas Daging Ikan tongkol. Skripsi. Surakarta:Universitas Sebelas Maret.

Aziz, T., S. Febrizki dan A.D. Mario. (2014). Pengaruh Jenis Pelarut terhadap persen Yieldalkaloid dari daun salam india (Murraya Koinigii).Teknik Kimia. 2(20):1-6.

Badan Standar Nasional Indonesia. (2006). Petunjuk Pengujian Organoleptik Dan Atau Sensori. SNI 01-23462006

Campbell. (2012). Biologi. Edisi 8. Jilid 1. Jakarta: Erlangga.

Fadhliani, (2020). Pengujian Antibakteri Ektrak Etanol Jukut Pendul (Kyllinga Brefivolia Rottb) Untuk Menghambat Pertumbuhan Bakteri Pathogen Eschericia Coli. Jurnal 
Biological Samudra 2(2); 114-120.

Hakim,R.R. (2010). Pengolahan dan Pengawetanikan.http://rizarahman.sta ff.umm.ac.id/files/2010/01/Pengolah an-ikan.pdf.

Manik, D.F., Hertiana, T. Dan Anshory. H., (2014) Analisis KulerasI Anatra Kadar Flavonoid dengan Aktivitas Antibakteri Ektrak Etanol dan Fraksin-fraksin dari Daun Kersen (Multingia calabura L) terhadap Staphilococcus aureus. Khazanah, 6, 2, 1-11.

Mardina V, Fitriani, Harmawan, T., Hildayani, G.M. (2018) Valorisasi Pankreas Ikan Tongkol (Eutynnus Affinis) Untuk Produksi Enzim Lipase. Elkawnie, 4 (2): 89 - 97.

Mardina, V., Halimatussakdiah, Harmawan, T., Ilyas, S., Tanjung, M., Aulya, W., \& Nasution, A. (2020). Preliminary phytochemical screening of different solvent extract of flower and whole plant of Wedelia biflora. IOP Conf. Series: Materials Science and Engineering 725 (2020) 012077.

Mardina V, Ilyas S, Harmawan T, Halimatussakdiah,Halimatussakdia h, Masitta Tanjung, (2020). Antioxidant and cytotoxin activaties of the ethyl acetate extract of Sphagneticola trilobata (L) J.F. Pruski on MCF-7 breast cencer cell. Jurnal of Advanced Pharmaceutical Tecnology \& Research, 11: 123 - 127.

Nigappan, Thilahgavani., Perunal Raamasamy., MohdEffendy Abdul Wahid., thirukanthan Chandra Sagarab and Charlas S. Vairappan (2011). Biological Activity of Carbazole Alkaloids and Essential Oil of Murraya Koenigii Against
Antibiotic Microbes and Cancer Cell Lines. Molecules, 16, 96519664.

Pelczar, M.J., dan Chan, E.C.S.. (2005). Dasar-dasar mikrobiolog 2. Jakarta: Universitas Indonesia

Peraturan Menteri Kesehatan Nomor 033 Tahun 2012 Tentang Bahan Tambahan Pangan.

Rastina, Sudarwanto, M. \&Wientarsis, I., (2015). Aktivitas Anti Bakteri Ekstrak Etanol Daun Kari (Murraya koenigii) Terhadap Staphilococcus Aureus, Escherichia Coli, Dan Pseudomas Sp. Jurnal Kedoktoran Hewan, 9 (2): 185-188.

Rasyid, Abdullah. (2016). Analisis Metabolit Sekunder, Aktivitas Anti Bakteri dan Komposisi Golongan Senyawa dalam Ekstrak Teripang Bohadschia Sp.

Rosiana, A. D. (2015). Pengawetan Ikan Nila (Oreochrombis niloticus) menggunakan Daun Sirihdengan Variasi Lama Perendaman yang Berbeda. Skripsi. Universitas Muhammadiyah Surakarta.

Sella, (2013). Analisis Pengawet Natrium Benzoat dan Pewarna Rhodamin B Pada Saus Tomat J dari Pasar Tradisional L Kota Blitar., Jurnal Ilmiah Mahasiswa Universitas Surabaya. Universitas Surabaya.

Standar Nasional Indonesia. SNI No. 012729.1-2006 Tentang Ikan Segar. Jakarta : Badan Standarisasi Nasional.

Sukma, Fisca Fajriani Sukma, Dinda Sahara, Furqan Nur Ihsan, Halimatussakdiah, Puji Wangyuningsih, Ulil Amma. (2018). Skrining Fitokimia Ekstrak Daun "Temurui" (Murayya koenigii L. Speng) Kota Langsa, Aceh. 


\section{Sumartini., Fronthea Swastawati, Tri Winarni Agustini. (2014). Analisis Asam Lemak Omega 3,6,9 Dan Kadar Fenol Ikan Bandeng (Channos channos Forsk) Asap Dengan Kombinasi Jarak Tungku Dan Lamapenasapan. Jurnal Pengolahan Dan Bioteknologi Hasil Perikanan. Vol : 3. No : 1 .}

Syifa, N., Bintari, S, H., dan Mustikaningtyas, D. (2013). Uji Efektivitas Ekstrak Bawang Putih (Alliumsativum) sebagai Antibakteri pada Ikan Bandeng (Chanos chanos). Unnes Journal Of Life Science. Vol 2. No 2.

Vitria, Belvi. (2016). Pengolahan Ikan Bandeng (Channos Channos) Tanpa Duri. Jurnal Ilmu Pengetahuan Dan Rekayasa. Hal 18-19.

\section{Vivi Mardina, Tisna Harmawan, Halimatussakdiah, Syafruddin Ilyas, dan Masitta Tanjung. (2020). Anticancer Activity of N-Hexane Extract from Sphagneticola trilobata (L.) J.F Pruski Against MCF-7 Breast Cancer Cell. Elkawnie, 6 (1): 48 - 58.}

Wafa, Ali, Anisa Ulfah, Oty Kiki, dan Moh Arham. (2014). Komhamdan" Program Kreatifitas Mahasiswa Bidang Pengabdian Masyarakat.

Wardini, T.,M., Retnani, Y., Dan Taryati. (2013). Pengaruh Estrak Daun Mengkudu Terhadap Profil Darah Puyuh Starter, JITP, 2(2): 114-115. 